\title{
Energy research and social sciences: thinking outside the box
}

\author{
Wadim Strielkowski ${ }^{1,2 *}$ \\ ${ }^{1}$ Prague Institute for qualification enhancement, Trnkovo nám. 1112/2, 15200 Prague, Czech Republic \\ ${ }^{2}$ Centre for Energy Studies, Prague Business School, Werichova str. 1145/29, 15200 Prague, Czech \\ Republic
}

\begin{abstract}
This paper aims at explaining the universality and broadness of the research in energy studies. Specifically, it wants to show that the energy research is not a solely engineering or natural sciences field and how it can be done in social sciences. The paper draws some relevant examples including energy research in literature and poetry, history, religion, art, as well in other social sciences and humanities. In general, it becomes apparent that energy research can boast vast depths and angles that are worth exploring for any social scientist. Given the key importance of energy research in the third decade of the $21^{\text {st }}$ century and the worldwide focus on the renewable energy sources, electrification of transport and heating in the face of the threatening global warming and climate change, it seems relevant to focus on researching the perspectives and paradigms for the traditional and renewable energy sources in the $21^{\text {st }}$ century using the toolbox of the social sciences.
\end{abstract}

\section{Introduction}

Energy and sustainable development issues have now become an essential part of our daily lives. We constantly read about sustainability and green energy and see them in the news, follow the discussions on oil and gas prices, read articles and blogs with reasoning about the safety of nuclear energy, as well as being bombarded with the accounts of the necessity to shift to the renewable energy sources (RES) or the electric vehicles that are going to help the humanity to embrace its carbon-free future $[1,2]$.

Replacing traditional energy production with RES is a multi-factor issue, the pros and cons of which are viewed differently by governments, technology companies, markets, and the general public $[3,4]$. There are significant public doubts about the advisability of investing in renewable energy sources. Research on energy and sustainable development in sociology and economics can focus on factors related to public opinion about renewable and traditional sources of energy [5,6].

One way or another, energy-related topics have found their way into social sciences and humanities. Energy research is no longer the domain of electrical engineers and technicians

\footnotetext{
* Corresponding author: strielkowski@prizk.cz
} 
but a broad and multidisciplinary area that attracts economists, sociologists, anthropologists, historians, or artists, just to name a few [7-9].

However, quite often we are confronted with the fact that social scientists cannot understand the full potential of energy research in social sciences and are reluctant to engage into pursuing the energy-related topics considering them too "technical" and "mathematical" $[10,11]$. This is far from truth - energy research is abundant in economic and social issues related to the energy production and consumption. For example, one can think of the interaction of various energy-related activities and processes with social structures that shape the interaction of people with the energy system. This is due to the fact that energy production, distribution and consumption have both technical and human components. Energy-related research features many social issues such as the relationship between energy consumption and energy security, energy efficiency and renewable energies, as well as energy use and its effects on human health and their well-being.

This short but insightful paper is intended to explains the universality and broadness of the research in social sciences and humanities in the relation to the energy studies. The paper attempts to demonstrate how the energy research can be done and provide inspiration for the future research in this field. This work draws from many examples including energy research in literature and poetry, history, religion, art, as well in other social sciences and humanities.

\section{Materials and methods}

Energy production, distribution and consumption have both technical and human components. Indeed, there are a number of social and technical issues related to energy production and consumption and energy-related humanities [12, 13].

One can see that energy research in social sciences covers a wide range of topics that revolve around societal processes and influences, including the impact of energy on the health of the people that are affected by it as well as the impact of climate change [14].

The study of the social structures related to energy systems and the way in which people interact with them. The latter, in particular, resembles the interaction between energy and social systems, such as the relationship between the human body and the environment [15]. With the increasing interest in how this understanding could be directly translated into policy interventions, energy-related social sciences have been studied in a number of different ways. There are major differences between disciplines and sub-disciplines, which relate primarily to theorization, definition and research problems, but it should not be forgotten that social sciences in general and energy research in particular share many of the same principles and scientific approaches [16].

In addition, one should not forget about the interdisciplinary research that overlaps academic disciplines, sectors and policies and is increasingly expected to develop new insights and help to address various situations. In recent years, it was expected that the academic discipline of the social sciences and humanities would contribute to this new knowledge and touch upon the research in energy economics and policy, energy and religion, energy and philosophy, energy and arts and literature, just to name a few [17].

In the section that follows, this paper will present a series of examples of interdisciplinary energy research applied from a social science and humanistic perspective. All of them constitute the interdisciplinary cooperation between the social sciences and humanities in the energy sector. This approach would help to revert the situation which we often witness nowadays - researchers and policymakers continue to focus on only one side of the energy dilemma, and social, humanities, and arts sciences are marginalized in energy research. Surely, this has to change very soon. The one-sided emphasis on science raises many questions and leads to frustration. 


\section{Energy@Everywhere}

Let us show some practical examples from the energy research in social sciences that involve top-notch research and publications in prestigious academic journals and books. One can start with Economics and proceed towards other social sciences.

\subsection{Energy economics and sociology}

It is clear that Economics might be a science about the allocation of scarce resources but it is also an exciting field of research that studies energy as a commodity. Take electricity for example. In fact, electricity is a special commodity that has to be consumed as soon as it is produced and which cannot be effectively and sufficiently stored for long periods of time [18].

And there are also energy prices, tariffs, quotas and other elements that are deeply rooted in Economics. Quite often, these economic tools are not designed in a best way and customers suffer as a result of that. For example, Simshauser [19] investigated a case of Southeast Queensland in Australia which features one of the highest penetration rates of domestic solar photovoltaic (PV) panels in the world and found that the massive increase in solar PV resulted in a huge transfer of wealth and costs between customer groups due to unfair tariffs [20].

There are also topics in energy that can found its use in sociology. Public and social acceptance of energy project and initiatives, attitudes to the energy-related issues and threats are all at the crossroads of sociology and economics.

Moreover, economists and sociologists can study such issues as willingness-to-pay for various energy-related projects, for example the industrial $\mathrm{CO}_{2}$ capture and storage products and technologies [21]. Other good examples might be the public acceptance of renewable energy sources [22], behavioural changes thanks to the deployment of smart meters that help to save energy in households [23], the new approaches to the Corporate Social Responsibility (CSR) with regard to the development of energy projects $[24,25]$, or the perceived threats to urban energy networks [26].

\subsection{Energy and philosophy}

The topics of energy and sustainable development are also relevant in philosophy [27]. Why does a person need energy and how much? Should this energy be free or should one pay for it? Does a person know how to use it correctly? Will the person destroy our planet in pursuit of new sources of energy? Why are mineral deposits unevenly distributed across countries and continents? The mission of the philosophy of energy is to explore and clarify the space in which the so-called energy transition to sustainable energy development (also called "green innovation") and renewable energy is taking place [28].

\subsection{Energy and religion}

Energy is also a constituent part of the religion and religious studies. For example, there is an Energy@Cambridge's Grand Challenge called, 'In Search of “Good” Energy Policy' at the University of Cambridge that has an aim to identify optimal practices and principles for designing and implementing the best possible energy policies. A part of this Grand Challenge is a serious of workshops on the topic, some of which are dedicated to finding the links between energy and religion.

For example, one of these workshops established that Pope Francis's 2015 encyclical "Laudato Si': On Care for our Common Home" apparently makes a strong appeal about the necessity of integrating energy policies and environmental policies with social concerns and 
grasping that ecological debt and other imbalances represents the issues of social and moral justice [29].

\subsection{Energy in literature and arts}

Lots of attention is paid to energy projects and various endeavours related to the conquest of nature for the extraction of new deposits or forms of energy in the literature and poetry. These topics were especially popular during the grandiose construction projects and "Communist" projects of the Soviet era. One can recall poems like the following one:

\section{"Once the man river Dnieper told: \\ "I will lock you up with a wall! \\ You will be jumping from the top, Moving the machines along"}

\section{Samuil Marshak “The war with Dnieper” (1930) [30]. Own translation}

Energy and sustainability issues are also widely reflected in art and film [31]. Suffice it to recall the posters or mosaics of the Soviet era, which extolled industrialization, electrification, the use of the "peaceful atom" and so on to the skies (see Figure 1).
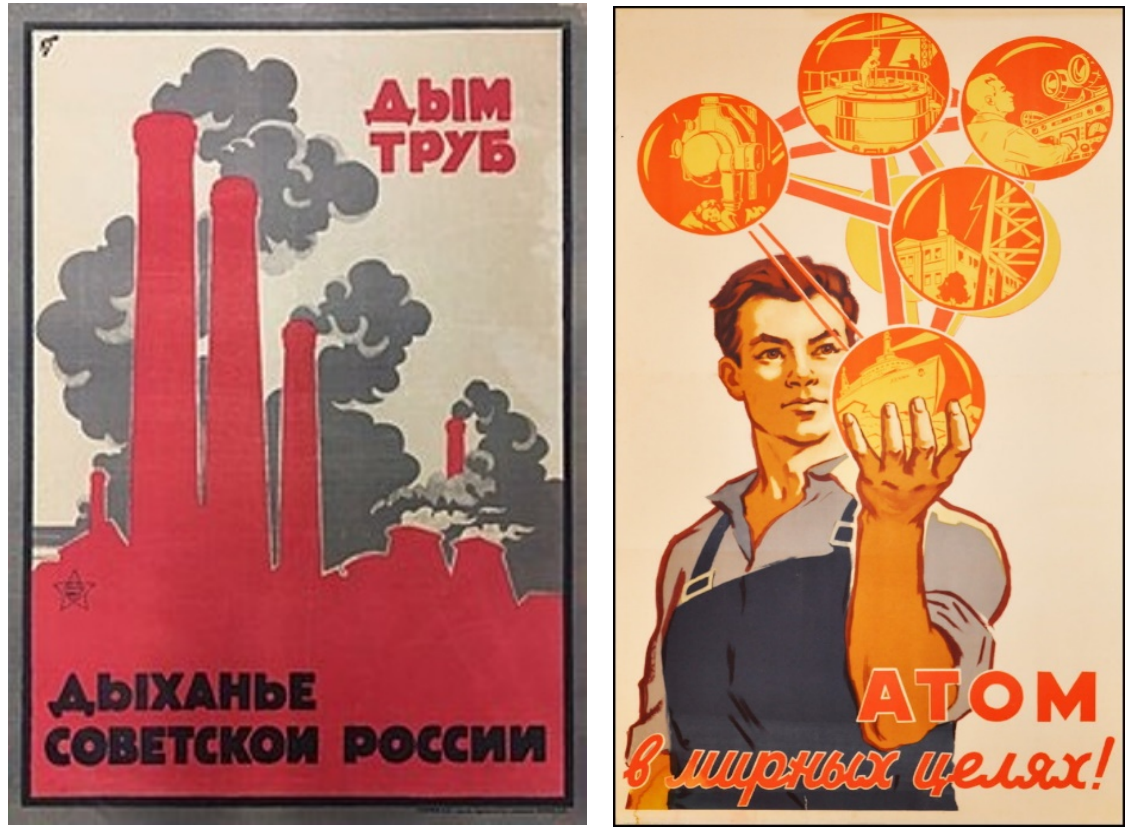

Fig. 1. Soviet era poster glorifying energy projects

Prior to the collapse of the Soviet Union, many films and TV series were made, in which the heroes conquered the virgin lands, performed the five-year plans in three years, or struggled with nature and its elements in the forests, steppes, mountains and seas of the endless Soviet Motherland.

Many of the energy-related stories of the Soviet era are reflected in contemporary cinema, both Russian and Western. Suffice it to recall the recently released HBO series Chernobyl (2019) that gained wide popularity among the viewers. 


\subsection{Energy and history}

The history of energy is an interesting topic in itself. Human history resembles a cycle: the new is always a well-forgotten past. Until the $18^{\text {th }}$ century and the Industrial Revolution, all energy produced by mankind for its own needs was renewable. Humans used horsepower to travel on land, wind power to travel across seas and oceans, burn wood in stoves and fireplaces to heat their homes, and harness the power of streams and rivers to run mills and other simple equipment. From today's perspective, all of these energy sources were renewable and sustainable.

One of the very interesting topics in the history of energy is the development of the electric power industry in the Soviet Union after the October Revolution of 1917 [32, 33]. The Soviet plan for the electrification of GOELRO was once admired by Herbert Wells, the famous science fiction writer and author of the bestseller "Time Machine" (1895).

\section{Conclusions}

There are various reasons why social scientist want and need to focus on the research in energy-related topics. First of all, it might be due to their multidisciplinary nature or the search for new exciting and unexplored topics for research. Second, it might be an attempt to publish their research in academic journal with high impact factor (the highest impact factor (IF) measured by the prestigious Web of Science database among the journals in the social sciences barely exceeds 5-6 with a median around 1-2, while in case of energy-related journals it can easily exceed 10 or be even higher). But most important of all is that social scientists need to learn how to think outside the box.

Overall, it becomes clear that energy research can boast vast depths and angles that are worth exploring for any social scientist. Given the key importance of energy research in the third decade of the $21^{\text {st }}$ century and the worldwide turn to the renewable energy sources, electrification of transport and heating in the face of the threatening global warming and climate change, it seems relevant to focus on researching the perspectives and paradigms for the traditional and renewable energy sources in the $21^{\text {st }}$ century.

The research in energy and energy-related issues must go beyond the dimensions of technology and economics and include social and human elements, as well as addressing issues such as the relationship between energy production, distribution and consumption and their impact on human health and well-being.

\section{References}

1. A. Pegels, G. Vidican-Auktor, W. Lütkenhorst, T. Altenburg, Journal of Environment \& Development, 27(1), 26-45 (2018)

2. W. Strielkowski, Economics and Sociology, 10(1), 310-318 (2017)

3. M. Wang, Y. Li, Z. Cheng, C. Zhong, W. Ma, Journal of Cleaner Production, 278, 123944 (2021)

4. I. Čábelková, V. Blaginin, W. Strielkowski, A. Platitsyn, E3S Web of Conferences, 208, 09001 (2020)

5. S. Ntanos, G. Kyriakopoulos, M. Chalikias, G. Arabatzis, M. Skordoulis, Sustainability, 10(3), 687 (2018)

6. I. Cábelková, W. Strielkowski, D. Streimikiene, F. Cavallaro, J. Streimikis, Technological Forecasting and Social Change, 163, 120477 (2021)

7. I. Ingeborgrud, S. Heidenreich, M. Ryghaug, T. Skjølsvold, C. Foulds, R. Robison, R. Buchman, R. Mourik, Energy Research \& Social Science, 63, 101398 (2020) 
8. M. Biresselioglu, M. Demir, B. Solak, A. Kayacan, S. Altinci, Science of The Total Environment, 729, 139027 (2020)

9. T. Dunlop, Energy Research \& Social Science, 56, 101216 (2019)

10. J. Markard, Nature Energy, 3(8), 628-633 (2018)

11. W. Strielkowski, Social Impacts of Smart Grids: The Future of Smart Grids and Energy Market Design (2019)

12. G. Sonetti, O. Arrobbio, P. Lombardi, L. Lami, S. Monaci, Energy Research \& Social Science, 61, 101342 (2020)

13. B. Van Veelen, A. Pinker, M. Tingey, G. Aiken, W. Eadson, Energy Research \& Social Science, 57, 101240 (2019)

14. S. Hallegatte, J. Rozenberg, Nature Climate Change, 7(4), 250-256 (2017)

15. C. Fontes, F. Freires, Renewable and Sustainable Energy Reviews, 82, 247-259 (2018)

16. H. Mohajan, Journal of Economic Development, Environment and People, 7(1), 23-48 (2018)

17. J. Koehrsen, S. Dickel, T. Pfister, S. Rödder, S. Böschen, B. Wendt, K. Block, A. Henkel, Current Sociology, 68(6), 738-760 (2020)

18. B. Dunn, H. Kamath, J. Tarascon, Science, 334(6058), 928-935 (2011)

19. P. Simshauser, Australian Economic Review, 47(4), 540-562 (2014)

20. W. Strielkowski, D. Štreimikienè, Y. Bilan, Renewable and Sustainable Energy Reviews, 77, 461-473 (2017)

21. V. Kashintseva, W. Strielkowski, J. Streimikis, T. Veynbender, Energies, 11(10), 2787 (2018)

22. I. Čábelková, W. Strielkowski, I. Firsova, M. Korovushkina, Energies, 13(7), 1742 (2020)

23. G. Rausser, W. Strielkowski, D. Štreimikienè, Energy \& Environment, 29(1), 131-146 (2018)

24. J. Lu, L. Ren, S. Yao, J. Qiao, W. Strielkowski, J. Streimikis, Energies, 12(18), 3417 (2019)

25. J. Lu, L. Ren, J. Qiao, S. Yao, W. Strielkowski, J. Streimikis, Sustainability, 11(15), $4128(2019)$

26. I. Čábelková, W. Strielkowski, F. Wende, R. Krayneva, Energies, 13(21), 5659 (2020)

27. J. Rendtorff, Philosophy of management and sustainability: Rethinking business ethics and social responsibility in sustainable development (2019)

28. R. Geerts, B. Gremmen, J. Jacobs, G. Ruivenkamp, Towards a philosophy of energy, Scientiae Studia, 12(SPE), 105-127 (2014)

29. J. Chaplin, From Inspiration to Implementation: Laudato Si', Public Theology and the Demands of Energy Policy. In: M. Ozawa, J. Chaplin, M. Pollitt, D. Reiner, P. Warde, (eds.) In Search of Good Energy Policy, 257-270 (2019)

30. Culture.ru, https://www.culture.ru/poems/42772/voina-s-dneprom (2021)

31. I. Samorukova, Vestnik of Samara University: History, pedagogics, philology, 23(4), 59-68 (2017)

32. A. Gibadullin, Statistika i Ekonomika, 15(1), 17-24 (2018)

33. R. Davies, R. Davies, M. Harrison, S. Wheatcroft (eds.), The economic transformation of the Soviet Union, 1913-1945 (1994) 